\title{
Competitive strategies of soft corals (Coelenterata: Octocorallia): III. Spacing and aggressive interactions between alcyonaceans* $^{*}$
}

\author{
S. C. La Barre ${ }^{1}$, J. C. Coll ${ }^{1} \&$ P. W. Sammarco ${ }^{2}$ \\ 1 Department of Chemistry and Biochemistry, James Cook University of North Queensland, Townsville, Queensland 4811, \\ Australia \\ ${ }^{2}$ Australian Institute of Marine Science, P.M.B. No 3, M.S.O., Townsville, Queensland 4810, Australia
}

\begin{abstract}
Interactions were observed in the field between neighboring colonies of the alcyonacean octocoral Sinularia flexibilis (Quoy \& Gaimard) and Sinularia sp., as well as between Sarcophyton glaucum (Quoy \& Gaimard) and Sinularia sp. Visible effects observed included growth modification, stunting, scarring, and bleaching. Allelopathy was suspected as the cause. An experiment was performed to examine the responses of certain alcyonaceans to each other in competition for space and possible causes of the observed effects. Specimens of 3 species of erect soft corals (Sinularia flexibilis, Nephthea sp., and Alcyonium molle Dean) were collected and relocated in pairs under both contact and non-contact (close proximity) conditions at a depth of 3 to $5 \mathrm{~m}$ in Pioneer Bay, Orpheus Island, Queensland $\left(18^{\circ} 40^{\prime} \mathrm{S}, 145^{\circ} 30^{\prime} \mathrm{E}\right)$. Initial effects observed included tissue necrosis and destruction of polyps, especially in contact situations, followed by colony reorientation. Long-term visible damage was minimal because, in all cases, the colonies subsequently moved apart. These sessile organisms exhibit a spacing behaviour allowing them to maintain an 'individual distance' in the same manner as many sedentary or vagile organisms. This decreases the incidence of aggression and potentially destructive interactions. Alcyonacean corals possess numerous adaptations which allow them to survive both predation and competition for space.
\end{abstract}

\section{INTRODUCTION}

The acquisition and maintenance of living space is critical to the survival of sessile organisms, and intense competition for space among such organisms has been documented extensively. This competition tends to be of the interference rather than the exploitative type, i.e. access to a limiting resource, in this case space, is reduced by the presence of a competitor (Miller 1967, Case \& Gilpin 1974, Davies 1978, McNaughton \& Wolf 1979). This living space may be acquired:

(1) via growth interactions (e.g. Jackson 1977, Karlson 1980, Sammarco 1980, 1982, Inose 1982, Sammarco \& Carleton 1982);

(2) via aggressive or cannibalistic interactions (e.g.

- Contribution No. 301 from the Australian Institute of Marine Science
Johnson 1959, Lang 1973, Woodin 1974, Richardson et al. 1979, Levin 1981, Sheppard 1982);

(3) via feeding interactions (e.g. Buss 1980); or

(4) via allelopathy.

Allelopathy may be defined as the 'direct inhibition of one species by another using noxious or toxic chemicals' (Ricklefs 1979, see also Muller 1966, Muller et al. 1968, Whittaker \& Feeny 1971). Allelopathy has only been documented in 3 groups of sessile marine organisms - sponges (Porifera; Jackson \& Buss 1975, Jackson 1977, Sullivan et al. 1983), anemones (Bak \& Borsboom 1984), and soft corals (Coelenterata: Alcyonacea), which are abundant on many Indo-Pacific coral reefs (Benayahu \& Loya 1977, Nishihira 1981, Dinesen 1983). Approximately one-half of the soft coral species on the Great Barrier Reef are known to contain toxic compounds (Coll et al. 1982b, Coll \& Sammarco 1983). Although the toxins may play an anti-predatory role 
(Bakus 1971, 1976, 1981, Cameron 1976), they may also serve as an adaptation for use in competition for space against scleractinian corals. Some species of soft corals release toxic terpenes into the seawater, causing mortality in certain scleractinian corals in the absence of contact (Sammarco et al. 1983).

Laboratory experiments have demonstrated that some soft coral terpenes affect photosynthesis and respiration in certain scleractinian corals (Webb \& Coll 1983). Mortality can also be induced in scleractinian corals in the laboratory with soft coral terpenes at concentrations as low as 5 to $10 \mathrm{ppm}$ (Coll \& Sammarco 1983). The same scleractinian corals, however, are also capable of causing local mortality in a different set of soft corals, namely Nephthea brassica Kukenthal and Capnella lacertiliensis MacFayden (Sammarco et al. 1985).

Another adaptation of selective advantage to soft corals in competition for space is their ability to change their orientation and growth patterns. They can actually move across live tabulate scleractinian corals, leaving elaborate trails as evidence of this movement (La Barre \& Coll 1983).

Few studies have concentrated on competitive interactions between corals within the Octocorallia. Theodor $(1966,1971)$ performed a number of experiments on interspecific interactions between gorgonian octocorals, demonstrating clear dominance of some species over others. Tissue necrosis and disintegration were induced in the subordinate species at or near the zone of contact.

Here we demonstrate experimentally the occurrence of interspecific interference competition between alcyonacean corals. We also examine the processes involved in the interactions between these colonial organisms and the mechanisms by which they space themselves. The results of these experiments provide a possible explanation for the infrequent observation of such interactions in the field.

\section{MATERIALS AND METHODS}

All observations and experimentation in this study were performed on the fringing reef at 3 to $5 \mathrm{~m}$ depth in Pioneer Bay, Orpheus Island (Palm Island Group), central region of the Great Barrier Reef $\left(18^{\circ} 40^{\prime} \mathrm{S}\right.$, $\left.145^{\circ} 30^{\prime} \mathrm{E}\right)$. The site was chosen for its high abundance of soft corals (18\% of total live cover; La Barre 1984) and the potential for interactions between them (Fig. 1).

An experiment was initiated in May 1982. Colonies of each of 3 species of alcyonaceans - Sinularia flexibilis, Nephthea sp. (C-2939: Northern Territory
Museum number), and Alcyonium molle - were collected with attached substratum and tagged in situ. Fifteen pairs were established by cementing 5 colonies of each species with a colony of each of the other 2 species in small plastic flower pots. The pots were wired to a galvanized mesh frame located at $\sim 3 \mathrm{~m}$ depth. The pairs of alcyonacean colonies were cemented in contact with one another. 'Non-contact' was considered to be a situation where the 2 colonies could not make physical contact, polypal or otherwise, as assessed by visual examination of expanded colonies (distance $=\sim 2.5 \mathrm{~cm}$ ). Three specimens of each species considered in the experiment were cemented into individual flower pots alone as controls and monitored. Three specimens of each species, occurring naturally in the field in a position isolated from potential competitors, were also monitored throughout the study as undisturbed controls.

Responses of the colonies were recorded after $1 \mathrm{~d}$, $3 \mathrm{~d}, 4 \mathrm{wk}, 7 \mathrm{wk}, 12 \mathrm{wk}$, and $20 \mathrm{wk}$. Visible effects of any interactions were assessed for each pair of colonies under contact and non-contact conditions. Effects were identified as (1) localized tissue necrosis in the region of proximity or contact, (2) avoidance via 'bending away' or growth modification, and (3) movement or displacement of colonies away from one another. Controls were also assessed for these characters.

Two-way (time $x$ effect) and 3-way (time $x$ contact $x$ effect) contingency tests of independence were used to analyze the data (Sokal \& Rohlf 1981). Details of the specific results of these analyses may be found in the figure legends. Higher-order interactions will only be discussed if significant.

\section{RESULTS}

In overview, a temporal pattern emerged in the responses of all soft corals (Fig. 2). With respect to tissue necrosis, the overall response was rapid, occurring within $1 \mathrm{~d}$ and peaking after $4 \mathrm{wk}$. The avoidance response on the whole lagged behind the necrotic response by at least $2 \mathrm{~d}$ and remained high for 4 to $7 \mathrm{wk}$ after initiation of the experiment. In both of these types of responses, non-contact effects were significantly lower than contact effects.

In all pairings of soft corals, the movement response was the same. Although no movement was observed initially, all colonies exhibited movement away from each other after $4 \mathrm{wk}$, and this response continued for the duration of the experiment. In several cases, soft coral colonies moved to the extreme edge of the experimental containers (Fig. 3). No directed movement was observed in the controls.

Nephthea sp. caused a high degree of necrosis 

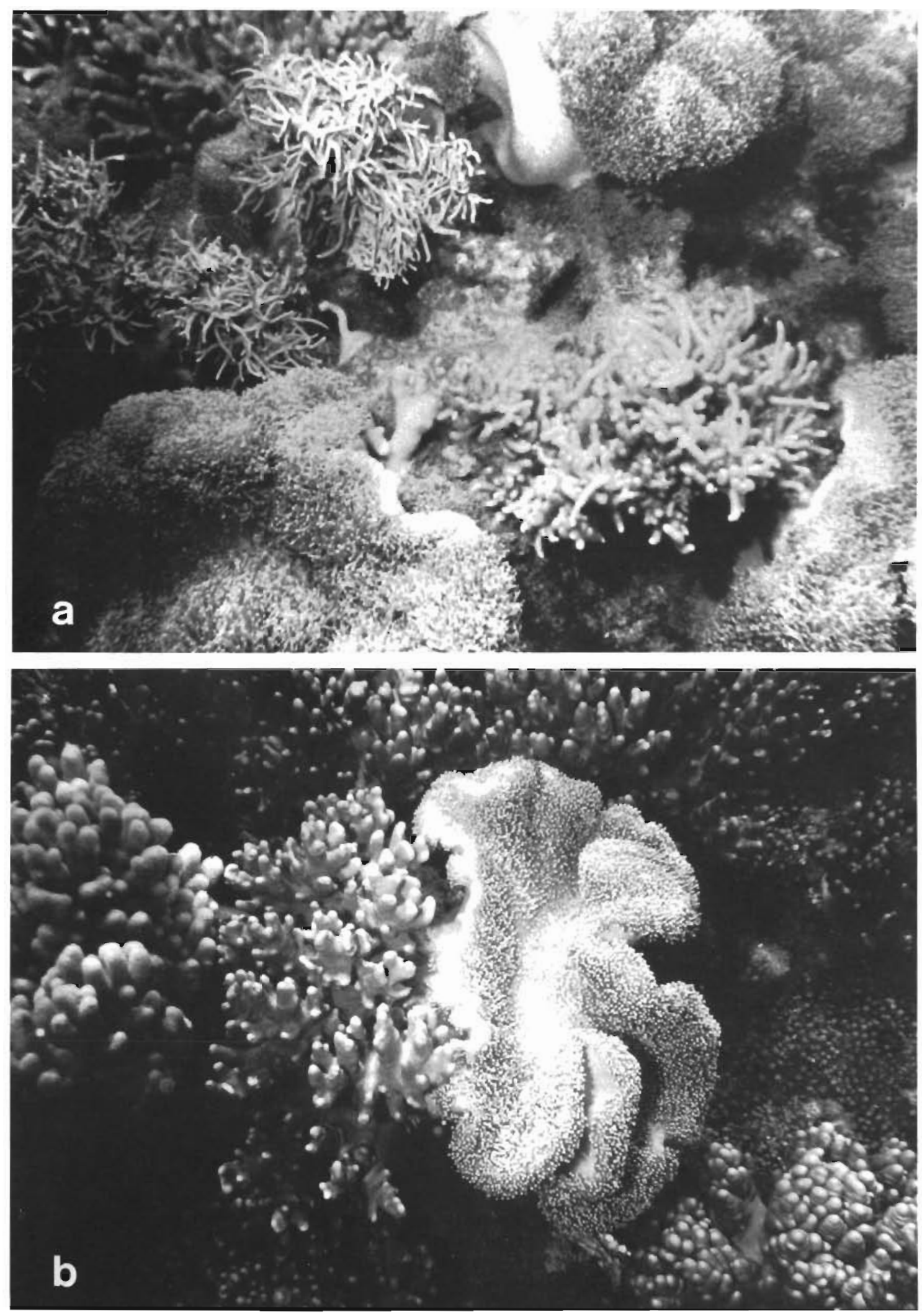

Fig. 1. (a) Sarcophyton glaucum. Three colonies observed exhibiting an avoidance response to Sinularia flexibilis under natural field conditions. (b) Sarcophyton glaucum exhibiting tissue necrosis in area of colony proximal to Sinularia sp. under natural field conditions 

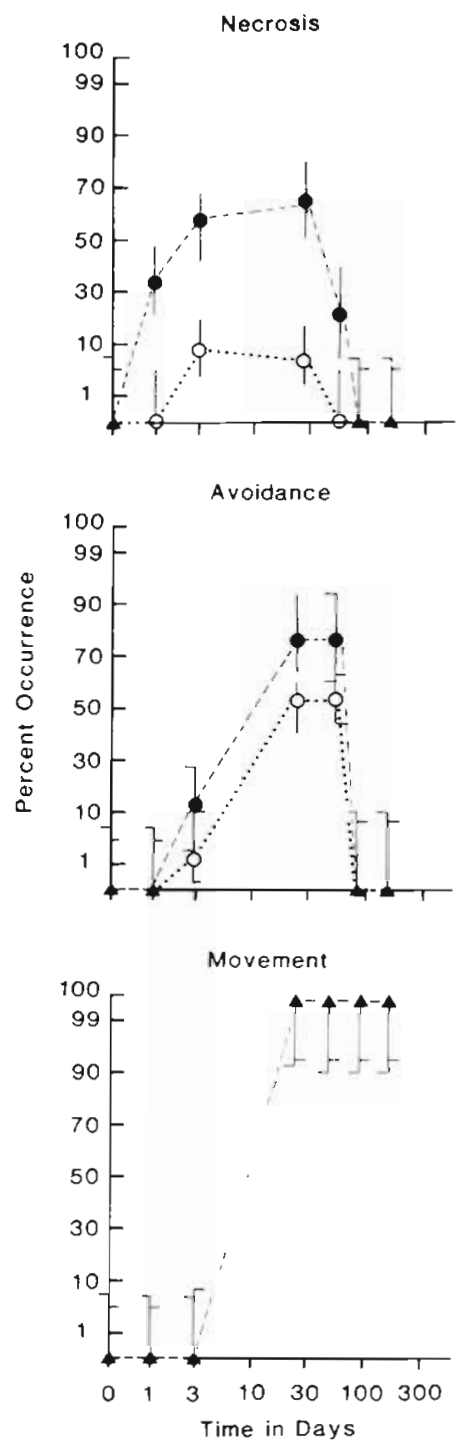

Fig. 2. Summary of effects of one species of soft coral upon another when placed in association experimentally in the field. Data shown through time with $95 \%$ confidence limits under $(\bullet$ ) contact conditions (with left-hand oriented confidence-limit demarcations where confidence intervals overlap); (O) non-contact conditions (with right-hand demarcations). (4): overlapping points. Data for necrosis, avoidance, and movement responses pooled, respectively, for all combinations of soft corals examined here

almost immediately when in contact with Sinularia flexibilis (Fig. 4). This strong initial reaction declined after $38 \mathrm{~d}$ and disappeared after $112 \mathrm{~d}$. Non-contact effects were indistinguishable from controls. By contrast, S. flexibilis had virtually no effect on Nephthea. Avoidance did not occur within the first few days of the experiment, but was consistently observed in both species under contact and non-contact conditions after $38 \mathrm{~d}$. This response ceased entirely after $112 \mathrm{~d}$.

Alcyonium molle initially induced significant ne- crosis in Sinularia flexibilis when in contact (Fig. 5) The effects increased further after $38 \mathrm{~d}$ and subsequently disappeared. Under non-contact conditions, significant necrotic effects were observed initially but quickly subsided. S. flexibilis also induced necrosis in A. molle under contact conditions, but it only reached significant levels after $38 \mathrm{~d}$. A. molle exhibited no necrosis under non-contact conditions. With respect to an avoidance response, $A$. molle and $S$. flexibilis both oriented away from each other in a manner similar to that described above, with the response occurring at the $38 \mathrm{~d}$ mark. The avoidance response of $A$. molle was less pronounced than that of Nephthea sp. under noncontact conditions.

Nephthea sp. induced significant necrotic effects in Alcyonium molle (Fig. 6). This occurred only under contact conditions. A. molle also induced highly significant levels of necrosis in Nephthea under both contact and non-contact conditions (Fig. 7). These effects subsided with time (Fig. 6). A. molle exhibited a more rapid avoidance response to Nephthea than any other combination of soft coral under contact conditions. Once again, this response peaked after $38 \mathrm{~d}$. Nephthea exhibited a strong avoidance response to $A$. molle after $38 \mathrm{~d}$, especially under contact conditions.

\section{DISCUSSION}

In this experimental study of competitive interactions between alcyonaceans, initial effects on the colonies somewhat paralleled effects previously observed between alcyonaceans and scleractinians (Sammarco et al. 1983). Tissue destruction and local mortality were all observed as a result of contact (and, in 1 case, noncontact) between the alcyonaceans during the first $3 \mathrm{~d}$ of the study. Thus, the interactions previously documented to occur between alcyonaceans and scleractinians should not be considered unique to those groups. That is, those same interference mechanisms documented are also effective between species within the Alcyonacea in competition for space. In addition, most interactions between pairings of alcyonacean species were 2-way; no clear hierarchy of dominance could be established. This suggests that a non-transitory competitive network similar to those reported for other benthic marine communities (Jackson \& Buss 1975, Connell 1976, Kay \& Keough 1981, Russ 1982) is also operating in Great Barrier Reef alcyonaceans

The necrotic effects observed here are similar to those reported by Theodor (1971) in the gorgonaceans. It seems probable that mucus-borne terpenes, which are known to be present in and released by certain soft corals (Coll et al 1982a) may be responsible for the 

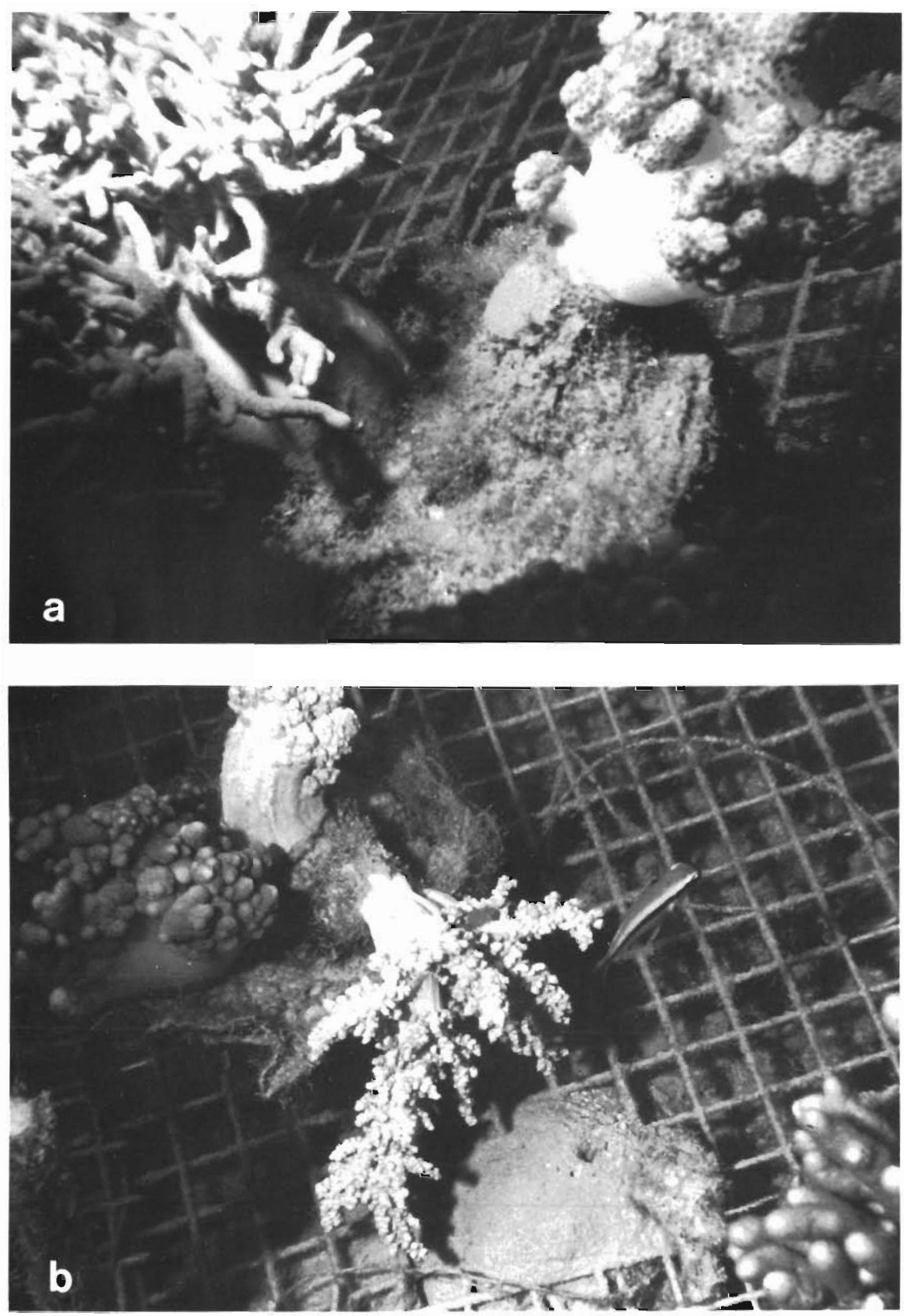

Fig. 3. (a) Movements in Nephthea sp. induced by Sinularia flexibilis after being placed in association experimentally in the field. (b) Movement response observed in both Nephthea sp. and Alcyonium molle under similar experimental conditions 

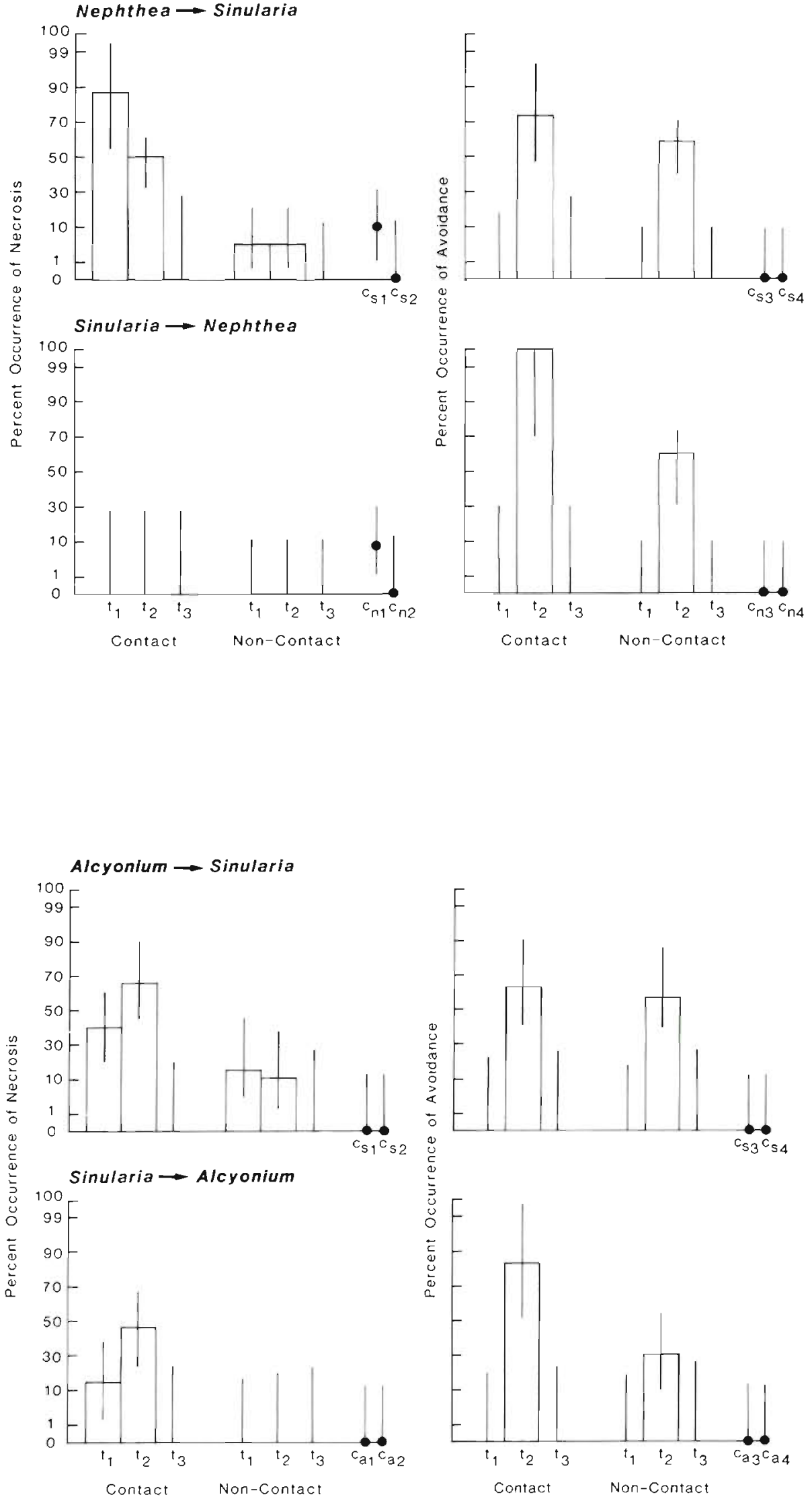

Fig. 5. The effects of Alcyonium molle on Sinularia flexibilis and vice-versa with respect to both necrosis (left-hand set of graphs) and avoidance (right-hand set). Data shown for 2,38 , and $112 \mathrm{~d}\left(\mathrm{t}_{\mathrm{i}}\right.$, $t_{2}, t_{3}$, respectively) under both contact and non-contact conditions. $95 \%$ confidence limits shown. $\mathrm{C}=$ levels of control response; codes similar to those in Fig. 4. Significant change in necrosis with time in both $S$. flexibilis ( $\mathrm{p}<0.001$, 3-way contingency analysis) and $A$. molle $(p<0.05)$. Necrosis significantly higher under contact conditions in both $S$. flexibilis $(p<0.01)$ and $A$. molle $(p<0.01)$. Significant change in avoidance with time in both $S$ flexibilis $(\mathrm{p}<0.001)$ and A. molle $(\mathrm{p}<0.001)$. Avoidance significantly higher under contact conditions in $A$. molle $(p<0.05)$ but not in S. flexibilis $(p>0.05)$ 
Fig. 6. The effects of Nephthea sp. on Alcyonium molle and vice-versa with respect to necrosis (lefthand graphs) and avoidance (right-hand graphs). Data shown for 2,38 , and $112 \mathrm{~d}\left(\mathrm{t}_{1}, \mathrm{t}_{2}, \mathrm{t}_{3}\right.$, respectively) under both contact and non-contact conditions with $95 \%$ confidence limits. $\mathrm{C}=$ levels of control response; codes similar to those in Fig. 4. Significant change in necrosis with time in both $A$. molle ( $\mathrm{p}<0.05,3$-way contingency analysis) and Nephthea $(\mathrm{p}<0.001)$. Necrosis significantly higher under contact conditions in both species $(p<0.001)$. Significant change in avoidance with time in both species $(p<0.001)$. Avoidance significantly higher under contact conditions in Nephthea $(\mathrm{p}<0.01)$ but not in A. molle ( $\mathrm{p}>0.05)$
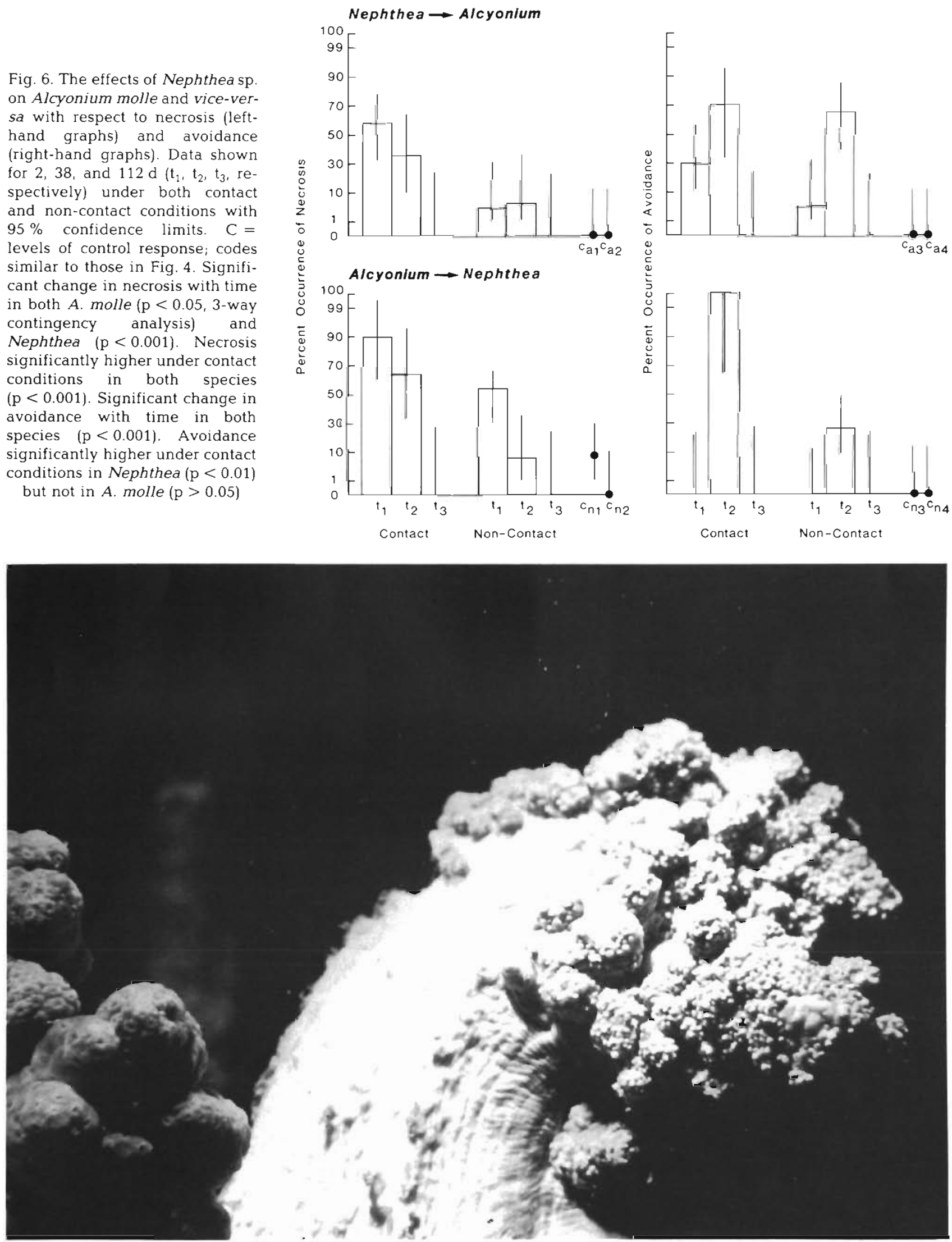

Fig. 7. Nephthea sp. Tissue necrosis induced by Alcyonium molle after being placed in contact under experimental conditions in the field 
tissue destruction. In fact, a laboratory study has shown that pure terpenes from Sinularia flexibilis and Lobophytum pauciflorum kill Acropora formosa and Porites andrewsi (Scleractinia) at concentrations as low as 5 to $10 \mathrm{ppm}$ (Coll \& Sammarco 1983). The coral tissue lyses, presumably following cell death, and the tissue falls away from the scleractinian skeletons after about $8 \mathrm{~h}$. Similar localised tissue destruction was observed in this study. Numerous other examples of tissue lysis appear in the literature relating to interspecific scleractinian grafts (Hildemann 1974, Hildemann et al. 1977)

In contrast to interactions between scleractinians and alcyonaceans, the alcyonaceans were able to alter their orientation to one another within several weeks by curving their sterile stalks, resulting in lack of contact. Once the soft corals were no longer in contact, a significant reduction in levels of antagonism occurred, allowing affected necrotic areas to heal. This 'bending' and the physiological mechanism responsible for it are probably similar to those reported for Nephthea brassica (Alcyonaceae) in its movement across Acropora hyacinthus (Scleractinia) (La Barre \& Coll 1983).

In all cases, after the soft corals suffered necrosis, they subsequently reoriented and then commenced to move apart. The timing of this movement was virtually identical in all species. In a previous study (La Barre \& Coll 1983), it was determined that reorientation consistently preceded movement (also see Benayahu \& Loya 1981).

These alcyonaceans seem to straddle the boundary between sessile and sedentary organisms. At first, they exhibited aggressive interaction, causing apparently chemically mediated damage to one another upon contact in much the same way as has been observed in some sessile organisms such as sponges (Jackson \& Buss 1975). But, in the longer term, they moved and agonistic interactions subsided, as observed in some sedentary and vagile organisms such as anemones (Francis 1973, Ayre 1982), polychaetes (Woodin 1974, Levin 1981). tube-dwelling amphipods, and fiddler crabs (Connell 1963). This avoidance behaviour resulted in the maintenance of an 'individual distance' (Conder 1949) which is known to promote coexistence among competing species (Davies 1978). This type of interaction is also known to affect the overall pattern of dispersion of both plants and animals in space. In fact, the pattern of dispersion in these animals could easily be a result of past interference and competition for space (Pielou 1960, Crisp 1961, Laessle 1965, Whittaker 1975. Fonteyn \& Mahall 1981).

Alcyonacean/alcyonacean interactions are much less commonly observed in the field than scleractinian/ alcyonacean interactions. Even at the relatively high densities observed in Pioneer Bay, Orpheus Island, colonies of certain co-occurring alcyonacean species are not found in contact. The 2 examples of deleterious interactions shown in Fig. 1 thus represent the exception rather than the rule at any one time. This mechanism for avoidance of competition represents one adaptation which may contribute to the continued coexistence of certain soft corals within a community. Each contains potently toxic terpenes which, at least in Sinularia flexibilis, are released into the surrounding seawater (Coll et al. 1982a). This character may also assist them in maintaining space via allelopathic interactions with other sessile organisms.

The combination of avoidance behaviour, movement, and allelopathic capabilities confers considerable adaptive advantage upon the soft corals studied here.

\section{CONCLUSIONS}

The major results of this study may be summarised as follows:

(a) With respect to competition for space between the alcyonacean corals Sinularia flexibilis, Nephthea sp., and Alcyonium molle, significant tissue necrosis was observed in almost all cases within 1 to $3 \mathrm{~d}$ where contact between colonies occurred. Necrosis also occurred under non-contact conditions but much less commonly.

(b) All species exhibited a significant avoidance response ('bending-away' or reorientation) within $3 \mathrm{~d}$ of being placed in contact with or mere proximity to each other.

(c) In all cases, soft corals exhibited movement away from each other (actual displacement of the colony) after the initial avoidance response. This movement was significant after $4 \mathrm{wk}$ and continued thereafter. To the level of temporal resolution examined here, the timing of this response was identical in all cases.

(d) The combination of allelopathy with avoidance behavior and the ability to move confers an important adaptive advantage on alcyonacean corals in competition for space with other sessile reef organisms.

Acknowledgements. We thank the Australian Institute of Marine Science for the use of their facilities and ships; the Marine Sciences and Technologies Grants Scheme for providing financial assistance for the project and specifically for a post-graduate research fellowship to S. La Barre. We thank R. Willis, B. Bowden, F. Coll, and C. Waid for assistance in the field, and J. H. Carleton for assistance with data analysis. We are grateful to P. Alderslade of the Northern Territory Museum for taxonomic identifications. Use of the Orpheus Island Research Station is also acknowledged. The manuscript has benefited greatly from comments by G. Russ, P. Moran, and A. Dartnall. 


\section{LITERATURE CITED}

Ayre, D. J. (1982). Inter-genotype aggression in the solitary sea anemone Actinia tenebrosa. Mar. Biol 68: 199-205

Bak, R. P. M., Borsboom, J. C. A. (1984). Allelopathic interaction between a reef coelenterate and benthic algae. Oecologia (Berl.) 63: 194-198

Bakus, G. J. (1971). An ecological hypothesis for the evolution of toxicity in marine organisms. In: De Vries, A., Kochva, A. (ed.) Toxins of animal and plant origin, Vol. 1. Gordon and Breach, London, p. 57-62

Bakus, G. J. (1976). The biology and ecology of tropical holothurians. In: Jones, O. A., Endean, R. (ed.) Biology and geology of coral reefs, Vol. 2. Academic Press, New York, p. $325-367$

Bakus, G. J. (1981). Chemical defense mechanisms on the Great Barrier Reef, Australia. Science 211: 497-499

Benayahu, Y., Loya, Y. (1977). Space partitioning by stony corals, soft corals, and benthic algae on the coral reefs of the northern Gulf of Eilat (Red Sea). Helgoländer Meeresunters. 30: 362-382

Benayahu, Y., Loya, Y (1981). Competition for space among coral-reef sessile organisms at Eilat, Red Sea. Bull, mar. Sci. 31: 514-522

Buss, L. W. (1980). Bryozoan overgrowth interactions - the interdependence of competition for space and food. Nature, Lond. 281 (5731): 475-477

Cameron, A. M. (1976). Toxicity of coral reef fishes. In: Jones, O. A., Endean, R. (ed.) Biology and geology of coral reefs, Vol. 3. Academic Press, New York. p. 155-176

Case, T. J., Gilpin, M. E. (1974). Interference competition and niche theory. Proc. natn. Acad. Sci. U.S.A. 71: 3073-3077

Coll, J. C., Bowden, B. F., Tapiolas, D. M., Dunlap, W. C. (1982a). In situ isolation of allelochemicals released from soft corals (Coelenterata: Octocorallia): a totally submersible sampling apparatus. J. exp. mar. Biol. Ecol. 60: 293-299

Coll, J. C., La Barre, S., Sammarco, P. W., Williams, W. T. Bakus, G. J. (1982b). Chemical defences in soft corals (Coelenterata: Octocorallia) of the Great Barrier Reef: A study of comparative toxicities. Mar. Ecol. Prog. Ser 8: $271-278$

Coll, J. C., Sammarco, P. W. (1983). Terpenoid toxins of soft corals (Cnidaria, Octocorallia): their nature, toxicity, and ecological significance. 7th World Congr. Anim. Plant Microb. Toxins, Brisbane, Australia, 11-16 July, 1982. Toxicon 1983, Suppl, 3: 69-72

Conder, P. J. (1949). Individual distance. Ibis 91: 649-655

Connell, J. H. (1963). Territorial behaviour and dispersion in some marine invertebrates. Res. Popul. Ecol. (Kyoto) 5: $87-101$

Connell, J. H. (1976). Competitive interactions and the species diversity of corals. In: Mackie, G. O. (ed.) Coelenterate ecology and behavior. Plenum, New York, p. 51-58

Crisp, D. J. (1961). Territorial behaviour in barnacle settlement. J. exp. Biol. 38: 429-446

Davies, N. B. (1978). Ecological questions about territorial behaviour. In: Krebs, J. R., Davies, N. B (ed.) Behavioral ecology, an evolutionary approach. Sinauer Assocs., Sunderland, Massachusetts, p. 317-350

Dinesen, Z. D. (1983). Patterns in the distribution of soft corals across the central Great Barrier Reef. Coral Reefs 1 (4); $229-236$

Fonteyn, P. J., Mahall، B. E. (1981). An experimental analysis of structure in a desert plant community. J. Ecol. 69 (3): $883-896$

Francis, L. (1973). Intraspecific aggression and its effect on the distribution of Anthopleura elegantissima and some related sea anemones. Biol. Bull. mar. biol. Lab., Woods Hole 144: 73-92

Hildemann, W. H. (1974). Some new concepts in immunological phylogeny. Nature, Lond. 250: 116-120

Hildemann, W. H., Hull, C. J., Akaka, L. K., Okamoto, J., Cheung, G. P. (1977). Tissue transplantation immunity in corals. Proc. 3rd Int. Coral Reef Symp. Rosenstiel School of Marine and Atmospheric Sciences. Univ. Miami, Vol. 1, p. $538-543$

Inose, M. (1982). A tree growth model based on crown competition in todomatsu (Abies sachalinensis). I. The relationship between crown development and volume increment. Bull. For. and For. Prod. Res. Inst. 0 (318): 103-128

Jackson, J. B. C. (1977). Competition on marine hard substrata: the adaptive significance of solitary and colonial strategies. Am. Nat. 111: 743-767

Jackson, J. B. C., Buss, L. (1975). Allelopathy and spatial competition among coral reef invertebrates. Proc. natn. Acad. Sci. U.S.A. 72: 5160-5163

Johnson, R. G. (1959). Spatial distribution of Phoronopsis viridis Hilton. Science 129: 1221

Karlson, R. H. (1980). Alternative competitive strategies in a periodically disturbed habitat. Bull. mar. Sci. 30 (4): 894-900

Kay, A. M., Keough, M. J. (1981). Occupation of patches in the epifaunal communities on pier pilings and the bivalve Pinna bicolor at Edithburg, South Australia. Oecologia (Berl.) 48: 123-130

La Barre, S. (1984). Studies in the chemical ecology of Alcyonarians (Coelenterata: Octocorallia). Ph. D. dissertation, James Cook Univ. N.Q., Townsville, Queensland, p. $1-348$

La Barre, S., Coll, J. C. (1983). Movement in soft corals: A growth interaction between Nephthea brassica (Coelenterata: Octocorallia) and Acropora hyacinthus (Coelenterata: Scleractinia). Mar. Biol. 72: 119-124

Laessle, A. M. (1965). Spacing and competition in natural stands of sand pine. Ecology 46: 65-72

Lang, J. C. (1973). Interspecific aggression by scleractinian corals. II. Why the race is not only to the swift. Bull. mar. Sci. 23: 261-279

Levin, L. A. (1981). Dispersion, feeding behaviour, and competition in two spionid polychaetes. J, mar. Res. 39: 99-117

McNaughton, S. J., Wolf, L. L. (1979). General ecology. 2nd edn. Holt, Rinehart, and Winston, New York

Miller, R. S. (1967). Pattern and process in competition. Adv. ecol. Res. 4: 1-74

Muller, C. H. (1966). The role of chemical inhibition (allelopathy) in vegetational composition. Bull. Torrey bot. Club 93: 332-351

Muller, C. H., Hanawalt, R. B., McPherson, J. K. (1968). Allelopathic control of herb growth in the fire cycle of California chapparal. Bull. Torrey bot. Club 95: 225-231

Nishihira, M. (1981). Interactions of Alcyonaria with hermatypic corals on an Okinawan reef flat. In: Gomez, E., Birkeland, C. E., Buddemeier, R. W., Johannes, R. E., Marsh, J. A. Jr., Tsuda, R. T. (ed.) The reef and man. Proc. 4 th Int. Coral Reef Symp., Univ. Philippines, Manila, Vol. 1, p. 722

Pielou, E. C. (1960). A single mechanism to account for regular, random, and aggregated populations. J. Ecol. 48: $575-584$

Richardson, C. A., Dustan, P., Lang, J. C. (1979). Maintenance of living space by sweeper tentacles of Montastrea cavernosa, a Caribbean reef coral. Mar. Biol. 55: 181-186 
Ricklefs, R. E. (1979). Ecology, 2nd edn. Chiron Press, New York

Russ, G. R. (1982). Overgrowth in a marine epifaunal community: Competitive hierarchies and competitive networks. Oecologia (Berl.) 53: 12-19

Sammarco, P. W. (1980). Diadema and its relationship to coral spat mortality: grazing, competition, and biological disturbance. J. exp. mar Biol. Ecol. 45: 245-272

Sammarco, P. W (1982). Echinoid grazing as a structuring force in coral communities: whole reef manipulations. J. exp. mar. Biol. Ecol. 61: 31-55

Sammarco, P. W., Carleton, J. H. (1982). Damselfish territoriality and coral community structure: reduced grazing and effects on coral spat. In: Gomez, E., Birkeland, C. E., Buddemeier, R. W., Johannes, R. E., Marsh, J. A. Jr., Tsuda, R. T (ed.) The reef and man. Proc. 4th Int. Coral Reef Symp., Univ. Philippines, Manila, 1981, Vol. 2, p. 525-535

Sammarco, P. W., Coll, J. C., La Barre, S., Willis, B. (1983). Competitive strategies of soft corals (Coelenterata: Octocorallia): Allelopathic effects on selected scleractinian corals. Coral Reefs 1: 173-178

Sammarco, P. W., Coll, J. C., La Barre, S. (1985). Competitive strategies of soft corals (Coelenterata: Octocorallia) II. Variable defensive response and susceptibility to scleractinian corals. J. exp. mar. Biol. Ecol. 91: 199-215
Sheppard, C. R. C. (1982). Coral populations on reef slopes and their major controls. Mar. Ecol. Prog. Ser. 7: 83-115

Sokal, R. R., Rohlf, F. J. (1981). Biometry. W. H. Freeman and Co., San Francisco

Sullivan, B., Faulkner, D. J., Webb, L. (1983). Siphonodictidine, a metabolite of the burrowing sponges Siphonodictyon sp. that inhibits coral growth. Science 221: 1175-1176

Theodor, J. L. (1966). Contribution à l'étude des gorgones (V): Les greffes chez les gorgones: Etudes d'un système de reconnaissance de tissus. Bull. Inst. océanogr Monaco 1374: $1-8$

Theodor, J. L. (1971). Reconnaissance du 'self' ou reconnaissance du 'not self' Archs zool. exp. gén. 112: 113-116

Webb, L., Coll, J. C. (1983). Effects of alcyonarian coral terpenes on scleractinian coral photosynthesis and respiration. Proc. 7 th World Congr. Anim. Plant Microb. Toxins, Brisbane, 1982. Toxicon 1983, Suppl. 3, p. 485-488

Whittaker, R. H. (1975). Communities and ecosystems. MacMillan, New York

Whittaker, R. H., Feeny, P. P. (1971). Allelochemics: chemical interactions between species. Science 171: 757-770

Woodin, S. A. (1974). Polychaete abundance patterns in a marine soft-sediment enviromment: the importance of biological interactions. Ecol. Monogr. 44: 171-187 